NOTE

\title{
Repeatability and number of growing seasons for the selection of custard apple progenies
}

\author{
Julio César DoVale ${ }^{1^{*}}$, Paulo Sérgio Lima e Silva ${ }^{2}$, Gustavo Sessa Fialho ${ }^{1}$, Keny Henrique Mariguele $^{3}$ and Roberto Fritsche-Neto ${ }^{1^{*}}$
}

Received 5 May 2010

Accepted 22 September 2010

\begin{abstract}
This study aimed to estimate the repeatability coefficient and determine the minimum number of samples required for effective selection for yield of custard apple. Twenty progenies were evaluated in randomized blocks, five replications and four plants per plot. The fruits were collected, counted and weighed every two days of the year. Estimates of the repeatability coefficients were obtained by the methods of analysis of variance - ANOVA and principal components - PC. The estimates from the repeatability analysis of biennial data are higher than those based on individual years. The estimates of the PC method were accurate even in the first harvest, unlike ANOVA. Four biennia were sufficient to ensure effective progeny selection of custard apple.
\end{abstract}

Key words: Heritability, main componentes, Annonas quamosa $L$.

\section{INTRODUCTION}

In the breeding of perennial species the coefficient of repeatability is an important parameter because it allows effective early selection of superior plants and/or progenies (Dias and Kageyama 1998). The analysis of repeatability describes the correlation between successive measurements of a trait and can serve as a basis for the estimation of the likelihood that the initial superiority or inferiority of a genotype will remain over time and/or space.

When a trait of the same plant is measured ç times, the mean of these ç observations is an unbiased estimator of the genotypic value for this trait (Falconer 1989). The reason is that the phenotypic variance can be split into two components. One is the temporal variation, reflecting differences between successive measurements of each plant and has a purely environmental origin. The other is partly due to environmental, partly to genotypic variation and is useful to describe differences between plants.

The environmental conditions under which plants are grown, the trait nature and genetic properties of a population are factors that affect the estimate of repeatability. According to Cruz et al. (2004), repeatability corresponds to the maximum possible value of the broadsense heritability. Consequently, when the variance caused by the permanent environmental effects is minimized, repeatability approaches the heritability estimate. Thus, the repeatability coefficient provides information about the heritability of a trait. Another advantage is that high repeatability values indicate the possibility of predicting the real individual value with a relatively small number of measurements (Cornacchia et al. 1995). Therefore,

\footnotetext{
${ }^{1}$ Universidade Federal de Viçosa, Departamento de Fitotecnia, 36.570 000, Viçosa, MG, Brazil. *E mail: rfritscheneto@ gmail.com

${ }^{2}$ Universidade Federal Rural do Semi-Árido (UFERSA), Departamento de Ciências Vegetais, 59.625-900, Mossoró, RN, Brazil

${ }^{3}$ RiceTec Sementes Ltda., Rua 18 de Novembro, 341, Bairro Navegantes, 90240-040, Porto Alegre, RS, Brazil
} 
knowledge of the repeatability coefficient allows an efficient use of resources and time in the evaluation phase.

Several studies on repeatability are found in the literature for a variety of perennials such as coffee (Fonseca et al 2004), Barbados cherry (Lopes et al 2001), cocoa (Dias and Kageyama 1998, Carvalho et al 2002), peach (Albuquerque et al 2004) and grape (Souza Leão and Costa 2003). For the widely appreciated custard apple (Annonas quamosa L.), grown in many regions of Brazil, studies related to genetics and breeding of this species are rare or nonexistent (Silva et al 2007).

The objectives of this study were to estimate and compare repeatability coefficients and determine the minimum number of growing seasons required for an effective selection for custard apple yield.

\section{MATERIAL AND METHODS}

\section{Plant material and experimental development}

The experiment was conducted on the experimental farm Rafael Fernandes (lat $5^{\circ} 11^{\prime}$ S, long $37^{\circ} 20^{\prime}$ W and alt $18 \mathrm{~m}$ asl) of the Universidade Federal Rural do Semi Árido (UFERSA). Twenty custard apple progenies were selected for vigor in orchard nurseries of small fruit growers in the municipalities of Aracati-CE, Mossoró-RN and Serra do Mel-RN. The seedlings were planted in October 2000, in $60 \times 60 \mathrm{~cm} \times 60 \mathrm{~cm}$ pits, at a spacing of $5.0 \mathrm{~m} \times 4.5 \mathrm{~m}$. The cultural practices were performed according to the recommendations for the crop to ensure good health and adequate nutritional status of the plants and microsprinkler irrigation applied whenever necessary.

The progenies were evaluated in randomized blocks, five replications and four plants per plot. Since the traits were evaluated over a long period, the plots were subdivided; the progenies were evaluated at the plot and the growing seasons at the subplot level. The fruits were harvested per plant every two days during the entire fruiting period, and later counted and weighed. This procedure was applied in all six growing seasons.

\section{Statistical-genetic analysis}

The estimates of the repeatability coefficients were obtained by the methods of analysis of variance - ANOVA and principal components - PC. Two sources of variation (progenies and season) were used in the statistical model: $Y_{i j}=\mu+g_{i}+a_{j}+\varepsilon_{i j}$, where $Y_{i j}=$ observation referring to the $\mathrm{i}^{\text {th }}$ plant in the $\mathrm{j}^{\text {th }}$ measurement (growing season); $\mu=$ general mean, $g_{i}=$ effect of the $i^{\text {th }}$ plant under permanent environmental influence of ( $i=1,2, \ldots, 20$ progenies $), a_{j}=$ effect of the $j^{\text {th }}$ replication $(\mathrm{j}=1,2, . . ., 5)$ and $\varepsilon_{\mathrm{ij}}=$ experimental error associated with observation $\mathrm{Y}_{\mathrm{ij}}$.

The repeatability coefficient by the method of analysis of variance was estimated as:

$$
r=\frac{C \hat{O} V\left(Y_{i j}\right)}{\sqrt{\hat{V}\left(Y_{i j}\right) \hat{V}\left(Y_{i j^{\prime}}\right)}}=\frac{\hat{\sigma}_{g}^{2}}{\hat{\sigma}_{y}^{2}}=\frac{\hat{\sigma}_{g}^{2}}{\hat{\sigma}_{e}^{2}+\hat{\sigma}_{g}^{2}},
$$

where the genetic variance among progenies was given by

$$
\hat{\sigma}_{g}^{2}=\frac{(Q M P-Q M R)}{\eta},
$$

and the residual variance by $\hat{\sigma}_{e}^{2}=Q M R$, where $Q M P$ and $Q M R$ are the mean squares associated with the progeny effect and random variation, respectively, and $\eta$ the number of evaluation periods.

To estimate the repeatability coefficient by the technique of principal components, a correlation matrix between genotypes was determined for each pair of measurements (or trial period), given by:.

$$
R=\left[\begin{array}{cccc}
1 & \rho & \ldots & \rho \\
\rho & 1 & \ldots & \rho \\
\ldots & \ldots & \ldots & \ldots \\
\rho & \rho & \ldots & 1
\end{array}\right]_{\eta}
$$

Subsequently, the eigenvalues and associated normalized eigenvectors were determined. Of these, the eigenvectors whose elements have the same sign and magnitude are close to those that express the trend of genotypes to maintain the position in relation to others over the years. The proportion of the eigenvalue associated with this eigenvector is the estimate of the repeatability coefficient, given by: where: $\hat{\lambda}_{k}$ is the eigenvalue associated with eigenvector whose elements have the same sign and similar magnitudes.

To obtain the coefficient of determination $\left(R^{2}\right)$ and the number of measurements needed to predict the genotypic value of the progeny $\left(\eta_{0}\right)$ as related to the desired accuracy, the following expressions were used:

$$
R^{2}=\frac{\eta_{r}}{1+r(\eta-1)} \text { and } \eta_{o}=\frac{R^{2}(1-\hat{r})}{1+\hat{r}(\eta-1)} \text {. }
$$

All tests were performed using the statistical program SAS 9.1 (SAS Institute 2003).

Crop Breeding and Applied Biotechnology 11: 59-63, 2011 


\section{RESULTS AND DISCUSSION}

The results obtained by ANOVA, based on annual harvests, showed that in most situations the estimates of the repeatability coefficients were lower when the first growing season was taken into consideration (Table 1). These values were expected, since not all plants had begun production in the first growing season, probably due to genetic effects. Similar results were observed for coffee, where the repeatability estimates based on annual data increased when the first growing season was excluded (Bonomo et al 2004).

The repeatability coefficients were higher when estimated by PC than by ANOVA, even when including the first growing season (Table 2). It may be noted that, based only on the yield data of the first and second growing season, the repeatability coefficient by ANOVA was 0.27 and 0.65 by PC. Thus, by the PC technique just one measurement is enough to reach a coefficient of determination of $80 \%$, which would ensure an effective and early selection for fruit yield of superior custard apple progenies. Cornacchia et al. (1995) reported similar results for pine and Lopes et al (2001) for Barbados cherry.

In perennial species such as custard apple with an oscillating production mode, with high yield and flowering in one year and a decline in the following, the effect can vary in intensity and between genotypes, so the analysis of variance used to estimate the usual repeatability coefficient may fail to eliminate this additional component of experimental error which would lead to an underestimation of repeatability. However, the principal component method takes the cyclical behavior of a trait into account and makes the estimated repeatability coefficient more effective. Therefore, this method can obtain reliable estimates of genotypes in the first growing seasons for the selection of superior plants, resulting in cost and time savings.

The biennial analysis proved suitable for crops with a clear biennial effect. Thus, as this applies for custard apple, the estimates of the coefficients of repeatability and of determination $\left(R^{2}\right)$, as well as the number of measurements required for each $R^{2}$ were studied using ANOVA and PC considering the biennial fruit yield (Tables 3 and 4).

The repeatability estimates obtained by this method were higher than those based on annual data measurements, in which, considering the second and third biennium using ANOVA (Table 3), the repeatability estimate was 0.78 and $R^{2}$ above $90 \%$. Another interesting result is that by the PC, reliability (> 90\%) was achieved with only two measurements (Table 4). These results reinforce the idea that the grouping of growing seasons helps to

Table 1. Estimates of the coefficients of repeatability $(\hat{r})$ and of determination $\left(R^{2}\right)$ and of the number of measurements $\left(\eta_{o}\right)$, by the method of analysis of variance for fruit yield data of 20 custard apple progenies

\begin{tabular}{lcccrrrrr}
\hline \multirow{2}{*}{ Years } & \multirow{2}{*}{ Nr. of growing seasons } & $\hat{r}$ & \multirow{2}{*}{$\boldsymbol{R}^{2}(\%)$} & \multicolumn{5}{c}{ Nr. of measurements to obtain $\boldsymbol{R}^{\mathbf{2}}$} \\
\cline { 5 - 9 } & & & $\mathbf{8 0}$ & $\mathbf{8 5}$ & $\mathbf{9 0}$ & $\mathbf{9 5}$ & $\mathbf{9 9}$ \\
\hline $1^{\text {st }}$ and $2^{\text {nd }}$ & 2 & 0.27 & 42.82 & 10.68 & 15.14 & 24.04 & 50.75 & 264.41 \\
$2^{\text {nd }}$ and $3^{\text {rd }}$ & 2 & 0.52 & 68.60 & 3.66 & 5.19 & 8.24 & 17.39 & 90.65 \\
$3^{\text {rd }}$ and $4^{\text {th }}$ & 2 & 0.26 & 41.21 & 11.41 & 16.17 & 25.68 & 54.21 & 282.45 \\
$4^{\text {th }}$ and $5^{\text {th }}$ & 2 & 0.55 & 71.36 & 3.21 & 4.55 & 7.22 & 15.25 & 79.45 \\
$5^{\text {th }}$ and $6^{\text {th }}$ & 3 & 0.49 & 65.81 & 4.16 & 5.89 & 9.35 & 19.74 & 102.84 \\
$1^{\text {st }}$ to $3^{\text {rd }}$ & 3 & 0.41 & 67.47 & 5.79 & 8.20 & 13.02 & 27.49 & 143.23 \\
$2^{\text {nd }}$ to $4^{\text {th }}$ & 3 & 0.28 & 54.13 & 10.17 & 14.41 & 22.88 & 48.30 & 251.66 \\
$3^{\text {rd }}$ to $5^{\text {th }}$ & 3 & 0.45 & 70.87 & 4.93 & 6.99 & 11.09 & 23.42 & 122.05 \\
$4^{\text {th }}$ to $6^{\text {th }}$ & 4 & 0.58 & 80.72 & 2.87 & 4.06 & 6.45 & 13.61 & 70.91 \\
$1^{\text {st }}$ to $4^{\text {th }}$ & 4 & 0.23 & 54.69 & 13.25 & 18.77 & 29.81 & 62.94 & 327.96 \\
$2^{\text {nd }}$ to $5^{\text {th }}$ & 4 & 0.40 & 72.64 & 6.03 & 8.54 & 13.56 & 28.62 & 149.14 \\
$3^{\text {rd }}$ to $6^{\text {th }}$ & 5 & 0.50 & 79.84 & 4.04 & 5.72 & 9.09 & 19.19 & 99.99 \\
$1^{\text {st }}$ to $5^{\text {th }}$ & 5 & 0.33 & 71.27 & 8.06 & 11.42 & 18.14 & 38.29 & 199.51 \\
$2^{\text {nd }}$ to $6^{\text {th }}$ & 6 & 0.45 & 80.07 & 4.97 & 7.05 & 11.20 & 23.64 & 123.18 \\
$1^{\text {st }}$ to $6^{\text {th }}$ & 5 & 0.38 & 78.59 & 6.54 & 9.26 & 14.71 & 31.06 & 161.84 \\
\hline
\end{tabular}


JC DoVale et al.

Table 2. Estimates of the coefficients of repeatability $(\hat{r})$ and of determination $\left(R^{2}\right)$ and of the number of measurements $\left(\eta_{o}\right)$, by the method of principal components for fruit yield data of 20 custard apple progenies

\begin{tabular}{ccccccccc}
\hline \multirow{2}{*}{ Years } & \multirow{2}{*}{ Nr. of growing seasons } & \multirow{2}{*}{} & \multirow{2}{*}{$\boldsymbol{R}^{2}(\%)$} & \multicolumn{5}{c}{ Nr. of measurements to obtain $\boldsymbol{R}^{\mathbf{2}}$} \\
\cline { 5 - 9 } & 2 & 0.65 & 78.45 & 2.19 & 3.11 & 4.94 & 10.44 & 54.40 \\
\hline $1^{\text {st }}$ and $2^{\text {nd }}$ & 2 & 0.54 & 70.44 & 3.36 & 4.76 & 7.55 & 15.95 & 83.09 \\
$2^{\text {nd }}$ and $3^{\text {rd }}$ & 2 & 0.46 & 63.18 & 4.66 & 6.60 & 10.49 & 22.14 & 115.37 \\
$3^{\text {rd }}$ and $4^{\text {th }}$ & 2 & 0.59 & 74.09 & 2.79 & 3.96 & 6.29 & 13.29 & 69.23 \\
$4^{\text {th }}$ and $5^{\text {th }}$ & 2 & 0.53 & 69.65 & 3.49 & 4.94 & 7.84 & 16.56 & 86.28 \\
$5^{\text {th }}$ and $6^{\text {th }}$ & 3 & 0.61 & 82.66 & 2.52 & 3.57 & 5.67 & 11.96 & 62.31 \\
$1^{\text {st }}$ to $3^{\text {rd }}$ & 3 & 0.46 & 71.54 & 4.77 & 6.76 & 10.74 & 22.67 & 118.13 \\
$2^{\text {nd }}$ to $4^{\text {th }}$ & 3 & 0.59 & 81.34 & 2.75 & 3.90 & 6.19 & 13.08 & 68.13 \\
$3^{\text {rd }}$ to $5^{\text {th }}$ & 3 & 0.60 & 81.82 & 2.67 & 3.78 & 6.00 & 12.66 & 65.97 \\
$4^{\text {th }}$ to $6^{\text {th }}$ & 4 & 0.53 & 81.71 & 3.58 & 5.07 & 8.06 & 17.00 & 88.62 \\
$1^{\text {st }}$ to $4^{\text {th }}$ & 4 & 0.52 & 81.41 & 3.65 & 5.18 & 8.22 & 17.36 & 90.43 \\
$2^{\text {nd }}$ to $5^{\text {th }}$ & 4 & 0.60 & 85.75 & 2.66 & 3.77 & 5.98 & 12.63 & 65.79 \\
$3^{\text {rd }}$ to $6^{\text {th }}$ & 5 & 0.54 & 85.66 & 3.35 & 4.74 & 7.53 & 15.90 & 82.84 \\
$1^{\text {st }}$ to $5^{\text {th }}$ & 5 & 0.55 & 85.68 & 3.34 & 4.74 & 7.52 & 15.88 & 82.73 \\
$2^{\text {nd }}$ to $6^{\text {th }}$ & 6 & 0.56 & 88.22 & 3.20 & 4.54 & 7.21 & 15.22 & 79.30 \\
$1^{\text {st }}$ to $6^{\text {th }}$ & & & & & & & & $\mathbf{9 9}$ \\
\hline
\end{tabular}

Table 3. Estimates of the coefficients of repeatability $(\hat{r})$ and of determination $\left(R^{2}\right)$ and of the number of measurements $\left(\eta_{o}\right)$, by the method of analysis of variance for fruit yield data of 20 custard apple progenies grouped in biennia

\begin{tabular}{cccccrrrrrr}
\hline \multirow{2}{*}{ Biennia } & \multirow{2}{*}{$\begin{array}{c}\text { Nr. of growing } \\
\text { seasons }\end{array}$} & $\hat{r}$ & $\boldsymbol{R}^{2}(\%)$ & \multicolumn{5}{c}{ Nr. of measurements to obtain $\boldsymbol{R}^{\mathbf{2}}$} \\
\cline { 6 - 10 } & 2 & 0.34 & 51.25 & 7.62 & 10.79 & 17.14 & 36.18 & 188.53 \\
$1^{\text {st }}-2^{\text {nd }} / 3^{\text {rd }}-4^{\text {th }}$ & 2 & 0.78 & 87.77 & 1.11 & 1.58 & 2.51 & 5.29 & 27.57 \\
$3^{\text {rd }}-4^{\text {th }} / 5^{\text {th }}-6^{\text {th }}$ & 3 & 0.54 & 78.00 & 3.39 & 4.79 & 7.62 & 16.08 & 83.79 \\
$1^{\text {st }}-2^{\text {nd }} / 3^{\text {rd }}-4^{\text {th }} / 5^{\text {th }}-6^{\text {th }}$ & 3 & &
\end{tabular}

Table 4. Estimates of the coefficients of repeatability $(\hat{r})$ and of determination $\left(R^{2}\right)$ and of the number of measurements $\left(\eta_{o}\right)$, by the method of principal components for fruit yield data of 20 custard apple progenies grouped in biennia

\begin{tabular}{|c|c|c|c|c|c|c|c|c|}
\hline \multirow{2}{*}{ Biennia } & \multirow{2}{*}{$\begin{array}{c}\text { Nr. of growing } \\
\text { seasons }\end{array}$} & \multirow{2}{*}{$\hat{r}$} & \multirow{2}{*}{$R^{2}(\%)$} & \multicolumn{5}{|c|}{ Nr. of measurements to obtain $R^{2}$} \\
\hline & & & & 80 & 85 & 90 & 95 & 99 \\
\hline $1^{\text {st }}-2^{\text {nd }} / 3^{\text {rd }}-4^{\text {th }}$ & 2 & 0.50 & 66.34 & 4.06 & 5.75 & 9.13 & 19.28 & 100.47 \\
\hline $3^{\text {rd }}-4^{\text {th }} / 5^{\text {th }}-6^{\text {th }}$ & 2 & 0.82 & 89.84 & 0.90 & 1.28 & 2.04 & 4.30 & 22.39 \\
\hline $1^{\text {st }}-2^{\text {nd }} / 3^{\text {rd }}-4^{\text {th }} / 5^{\text {th }}-6^{\text {th }}$ & 3 & 0.63 & 83.80 & 2.32 & 3.29 & 5.22 & 11.02 & 57.42 \\
\hline
\end{tabular}

decrease the biennial effects in custard apple and that PC increases the magnitude and accuracy of repeatability estimates.

The coefficient of determination expresses the accuracy in predicting the actual plant value and the repeatability coefficient represents the consistency of genotypic superiority in successive measurements of the same plant. Thus, the reliability in the selection of the best custard apple progenies, based on the phenotypic value, may be higher depending on the biennia to be considered, since the accuracy was improved in the analysis of the second with the third, by ANOVA as well as PC.

In Robusta coffee, Fonseca et al. (2004) found that four crops are sufficient for an effective selection of 
superior plants. The results were extrapolated to six crops, leading to a small gain in accuracy of individual real value, indicating that the sixth harvest did not contribute significantly to increase accuracy. Consequently, a higher number of measurements is not linearly related to an increased accuracy of the actual plant value, and it would take a great number of samples to make the accuracy increase significant. In this study the second and third biennium were considered, and it was observed that a level of $95 \%$ reliability can be achieved by approximately five measurements, while 23 measurements would be required for $99 \%$, which would be impractical from the standpoint of genetic improvement. The time and cost invested in relation to the desired accuracy should therefore be taken into consideration.

The results show that the estimates resulting from analysis of repeatability based on biennial data are higher than those with individual years, and that four biennia are sufficient for an effective selection of custard apple progenies. Moreover, the estimates of PC analysis are accurate even in the first growing season, unlike ANOVA.

\section{Repetibilidade e número de colheitas para a seleção de progênies de pinheiras}

RESUMO - Este trabalho teve como objetivos estimar o coeficiente de repetibilidade e determinar o número mínimo de colheitas necessárias para a seleção acurada para produtividade de frutos em pinheira. Foram avaliadas 20 progênies no delineamento em blocos ao acaso com cinco repetições, com quatro plantas por parcela. Os frutos foram colhidos, contados e pesados a cada dois dias durante o ano inteiro. As estimativas dos coeficientes de repetibilidade foram obtidas pelos métodos da análise de variância - ANAVA e de componentes principais - CP. A análise de repetibilidade com dados acumulados em biênios apresentou estimativas superiores às obtidas utilizando anos individuais. O método CP gerou estimativas acuradas mesmo nas primeiras colheitas, diferentemente do método da ANAVA. Quatro biênios foram suficientes para a seleção acurada de progênies de pinheira.

Palavras-chave: Herdabilidade, componentes principais, Annona squamosa L.

\section{REFERENCES}

Albuquerque AS, Bruckner CH, Cruz CD, Salomão LCC and Neves JCL (2004) Repeatability and correlations among peach physical traits. Crop Breeding and Applied Biotechnology 4: 441-445.

Bonomo P, Cruz CD, Viana JMS, Pereira AA, Oliveira VR and Carneiro PCS (2004) Seleção antecipada de progênies de café descendentes de "híbrido de timor" x "catuaí amarelo" e "catuaí vermelho". Acta Scientiarum Agronomy 26: 91-96.

Carvalho CGP, Cruz CD, Almeida CMVC and Machado PFR (2002) Yield repeatability and evaluation period in hybrid cocoa assessment. Crop Breeding and Applied Biotechnology 2: 149-156.

Cornacchia G, Cruz CD, Lobo PR and Pires IE (1995) Estimativas do coeficiente de repetibilidade para características fenotípicas de procedências de Pinus tecunumanii (Schw.) Eguiluz, Perry e Pinus caribaea var. hondurensis Barret, Golfari. Revista Árvore 19: 333-345.

Cruz CD and Regazzi AJ (2004) Modelos biométricos aplicados ao melhoramento genético. Editora UFV, Viçosa, 390p.
Dias LAS and Kageyama PY (1998) Repeatability and minimum harvest period of cacao (Theobroma cacao L.) in Southern Bahia. Euphytica102: 29-35.

Falconer DS (1989) Introduction to quantitative genetics. Longman Press, London, 438p.

Fonseca AFA, Sediyama T, Cruz CD, Sakiyama NS, Ferrão RG, Ferrão MAG and Bragança SM (2004) Repeatability and number of harvests required for selection in robusta coffee. Crop Breeding and Applied Biotechnology 4: 325-329.

Lopes R, Bruckner CH, Cruz CD, Lopes MTG and Freitas GB (2001) Repetibilidade de características de frutos de aceroleira. Pesquisa Agropecuária Brasileira 36: 507-513.

SAS Institute (2003) SAS/STAT software 9.1. SAS, Cary (CD-ROM).

Silva PSL, Antônio RP, Mariguele KH, Silva KMB, Lima KL and Silva JCV (2007) Estimates of genetic parameters for fruit yield and quality in custard apple progenies. Revista Brasileira de Fruticultura 29: 550-558.

Souza Leão PCS and Costa JG (2003) Estimates of repeatability and path coefficients on grapes. Crop Breeding and Applied Biotechnology 3: 231-236. 